\title{
Слово редактора
}

Ось і завершується 2019 науковий рік для "Українського релігієзнавства". Цей рік був для нас, і редакції, i авторів, і рецензентів, випробувальним. Ніколи раніше ми не працювали в такому режимі, за новими правилами, на новій платформі. Але справились. Хочу нагадати, що з 2016 року наш журнал почав індексуватися в Науково-метричній базі Копернікус (journals.indexcopernicus.com). Тоді нам було присвоєно значення 37.62. Завдяки зусиллям авторів і рецензентів за 2017 рік він зріс до 75.19. Виконавши ряд вимог, наш журнал в 2018 році отримав рейтинг 87.60. Ми регулярно нарощуємо рівень виконання міжнародних умов для періодичних видань, чим наближаємося до Scopus i WoS.

89 номер "Українського релігієзнавства" структурно представлений традиційними вже для бюлетеня блоками.

Розділ Філософія релігї поповнився теоретичним матеріалом доктора філософських наук, декана філософсько-теологічного факультету Чернівецького національного університету ім. Ю.Федьковича Олександра Бродецького. Знаний фахівець з етичних проблем релігій представляє статтю, яка написана на основі його виступу на міжнародній конференції "Універсальні цінності релігій", що відбувалася в Києві в жовтні 2019. Автор глибоко і всебічно осмислює гуманістичний потенціал етичних ідей різних релігійних традицій та з'ясовує умови їхньої дієвості за сучасних умов. Цим матеріалом ми розпочинаємо дру- 
кувати виступи й інших учасників конференції, які вже надходять до редколегії журналу.

Розділ Iсторія релігії представлений цікавим дослідженням молодого вченого, кандидата філософських наук Олени Зайченко 3 Національного історико-меморіального заповідника «Биківнянські могили». Стаття базована на архівних матеріалах - справі репресованих селян 3 Київської обл., які належали до секти мальованців, засвідчує їх переслідування в першій половині XX ст.

Редакція продовжує публікацію статей, в яких досліджується історія релігієзнавсmba. Так, в представленому А.Колодним матеріалі аналізуються релігієзнавчі здобутки відомого вітчизняного філософа, багаторічного директора Інституту філософії ім. Г.С.Сковороди НАН України академіка Мирослава Поповича, який цікавився духовною історією наших предків, зокрема стародавніми віруваннями українців, в контексті загально культурних процесів, механізмами християнізації язичництва і оязичнення християнства, особливостями християнського віровчення.

Видання вибраних праць канадійського історика i релігієзнавця професора Ю.Мулика-Луцика під загальною назвою "Релігія в історії та духовності українців" спонукало молодого дослідника Георгія Филиповича проаналізувати деякі його твори, присвячені ідейним пошукам української діаспори Канади, які в середині XX ст. знаходилися в стані ідентифікаційних пошуків між етнічним партикуляризмом та інтернаціональним універсалізмом.

У попередньому 88 номері журналу в розділі $A p x i b u$ редакція розпочала друк спогадів засновників та активних членів Української асоціації релігієзнавців про ії заснування і перші роки діяльності. Природно, що після першого інтерв'ю, яке дав президент УАР професор А.M.Ко- 
лодний, наступним відповідає на запитання анкети перший вчений секретар УАР кандидат філософських наук, ст. науковий співробітник Михайло Бабій, на плечі якого лягла відповідальність документально оформити намагання уарівців заснувати професійну спілку дослідників релігії. Завдяки Михайлу Юхимовичу діяльність релігієзнавців відбувалася в правовому полі України, відповідно до Статуту як недержавної неприбуткової організації, яка доклалася до формування громадянського суспільства в Україні. Матеріали до друку підготувала Л.Филипович.

Про Академічне життя інформує ст. наук. співробітник Відділення релігієзнавства Ольга Недавня в своєму огляді Міжнародної наукової конференції "Універсальні цінності релігій", яку зорганізували УАР, ВРРО та Відділення релігієзнавства ІФ НАНУ. В Києві зібралися представники переважної більшості українських релігій, які щедро поділилися своїм розумінням універсалізму і цінностей. Матеріали конференції представлені вже в цьому номері і надалі поступово будуть друкуватися в наступних числах УР.

Розділ Рецензії поповнився інформаційно-аналітичним матеріалом доктора філософських наук П.Павленка на видану у 2019 р. колективну монографію "Релігійна безпека/небезпека України", яка вже зацікавила експертне середовище і є надзвичайно запитуваною.

В Інформації подані спростування помилкового авторства статті, надрукованої в "Українському релігієзнавстві" №73 в 2015 році, та подається попередній графік релігієзнавчих конференцій у 2020 р.

Ще раз звертаюсь до всіх, хто збирається співробітничати із журналом "Українське релігієзнавство", 
Українське релігієзнавство № 89

відповідальніше підходити до підготовки та подачі ваших матеріалів. Ми розуміємо, що можуть бути технічні труднощі, допомогти подолати які готові всі співробітники редакціï, зокрема адміністратор сайту. Він підготував для вас відео про процес подачі статті на платформі OpenJournalSystem: https://www.youtube.com/watch?v=1q_dP9f26Q

Просимо перед поданням матеріалів уважно переглянути підготовлений відеоролік. Переконаний, що ми разом успішно подолаємо всі складності, які чатують на науковців у справі публікацій наукових статей.

Щасти вам і нам в Новому 2020 році!

\section{Головний редактор Анатолій КОЛОДНИЙ}

